\title{
FINITE ELEMENT ANALYSIS OF FRAME WITH SOIL STRUCTURE INTERACTION
}

\author{
Gaikwad M.V', Ghogare R.B ${ }^{2}$, Vageesha S. Mathada ${ }^{3}$ \\ ${ }^{1}$ Assistant prof, Civil Dept. S.B.Patil college of engg. Indapur, Maharashtra, India \\ ${ }^{2}$ Assistant prof. Civil Dept. S.B.Patil college of engg. Indapur, Maharashtra, India \\ ${ }^{3}$ Prof Civil Dept. SVERI,s college of engg. Pandharpur, Maharashtra, India
}

\begin{abstract}
For the analysis of a building frame, the columns at the foundation level are considered as fixed. But in real condition it is not the case. While considering soil in the analysis of building frame $100 \%$ fixity may not be ensured. Because of the settlement and rotation of foundation, shear force and bending moment in superstructure get altered. This effect is called as "Soil Structure Interaction" Present work is to study behavior of bare frame \& in-filled frame having soil beneath. In these cases three types of soils are considered, soft, medium stiff and hard. Also in-filled panel is of brick masonry only. Various cases frames are studied. The following are the cases:
\end{abstract}

1] Analysis of bare frame with soil.2] Analysis of In-filled frame with Soil.3] Analysis of Bare frame without Soil.4] Analysis of In-filled frame without Soil Frame with different combinations mentioned above (with/without infill panel, with/without soil) is analyzed by using ANSYS 14.5. These results are comprised with SSI and without SSI.

Keywords: Soil Structure Interaction, In-Filled Frame, Bare Frame.

\section{INTRODUCTION}

Generally structure is analyzed and designed assuming fixed support at the foundation level and hence effect of compressibility of soil under the foundation is ignored. The effect of infill wall of the structure is also not taken in to consideration. The structure analyzed and designed in this way does not give the actual or realistic behavior. In actual condition the structure is generally supported on compressible soil mass. There exits interaction between structure and soil mass below foundation. The flexibility of foundation, the compressibility of soil mass and other factors play an important role in the redistribution of moments and shear forces in the superstructure because of differential settlement of soil mass.

\subsection{In-filled frame (Masonry Panel)}

An infill (masonry) panel is the partition wall or the cladding element used in the reinforced concrete or steel frame structure. They are normally considered as architectural elements. Engineers often ignored their presence. Because of complexity of the problem, their interaction with the bounding frame is often neglected in the analysis of building structures. This assumption may lead to an important inaccuracy in predicting the response of the structure. This occurs especially when subjected to lateral loading. Even though they are considered nonstructural they interact with the bounding frame when the structure is subjected to strong earthquake loads or lateral loads. This interaction may beneficial for structural performance, but sometimes this leads to strong damage.

\subsection{Soil Structure Interaction}

However, the structure always interacts with the soil to some extent during lateral loading, imposing soil deformations that cause the motions of the structure - soil interface to differ from those that would have been observed in the free field. The allowable movement of foundation and structure depends on soil structure interaction.

\section{PROPERTIES OF MATERIAL}

Properties for masonry material and components should be based on the available construction documents. The following material properties shall be obtained for the asbuild structure. [1] Soil beneath foundation can be any type of soil; it may be soft soil, may be rock or may be black cotton soil. So depending upon its type the engineering and mechanical properties of soils are decided using different types of tests. [2]

Table-1.Properties of different materials for analysis

\begin{tabular}{|c|c|c|c|}
\hline \multicolumn{2}{|c|}{ Material } & $\begin{array}{l}\text { Modulus of } \\
\text { Elasticity } \\
\left(\mathrm{KN} / \mathbf{m m}^{2}\right)\end{array}$ & $\begin{array}{l}\text { Poisson's } \\
\text { ratio }\end{array}$ \\
\hline \multicolumn{2}{|c|}{$\begin{array}{l}\text { In-filled panel (brick } \\
\text { masonry) }\end{array}$} & 15.4 & 0.15 \\
\hline \multicolumn{2}{|c|}{ Concrete } & 25 & 0.2 \\
\hline \multirow{3}{*}{ Soil } & Soft & 10 & 0.25 \\
\hline & Medium & 35 & 0.34 \\
\hline & hard & 80 & 0.45 \\
\hline \multicolumn{2}{|c|}{ Steel } & 200 & 0.3 \\
\hline
\end{tabular}




\section{VALIDATION}

Analysis of in-filled frames to resist lateral loads on buildings in terms of their failure modes, failure loads, and initial stiffness tested by previous author Riddington is verified. This verification is made by comparing the results of the analytical procedures of the previous authors with those of a finite element model for in-filled frames, which are verified using ANSYS14.5. [12]

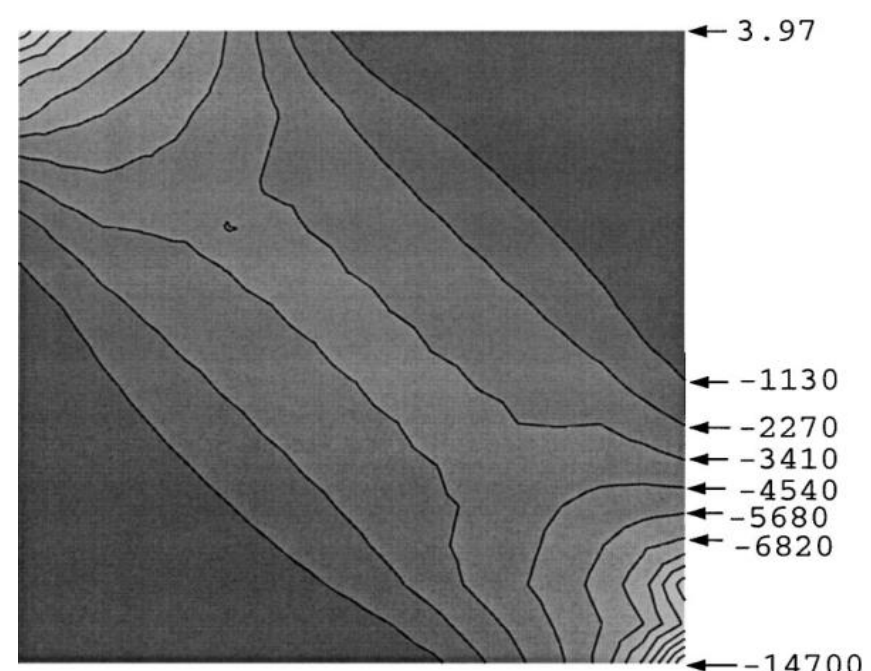

Fig.1 Riddington stiff frame: minimum principal stress $\left(\mathrm{KN} / \mathrm{m}^{2}\right)$ plot at lateral load $460 \mathrm{KN}$

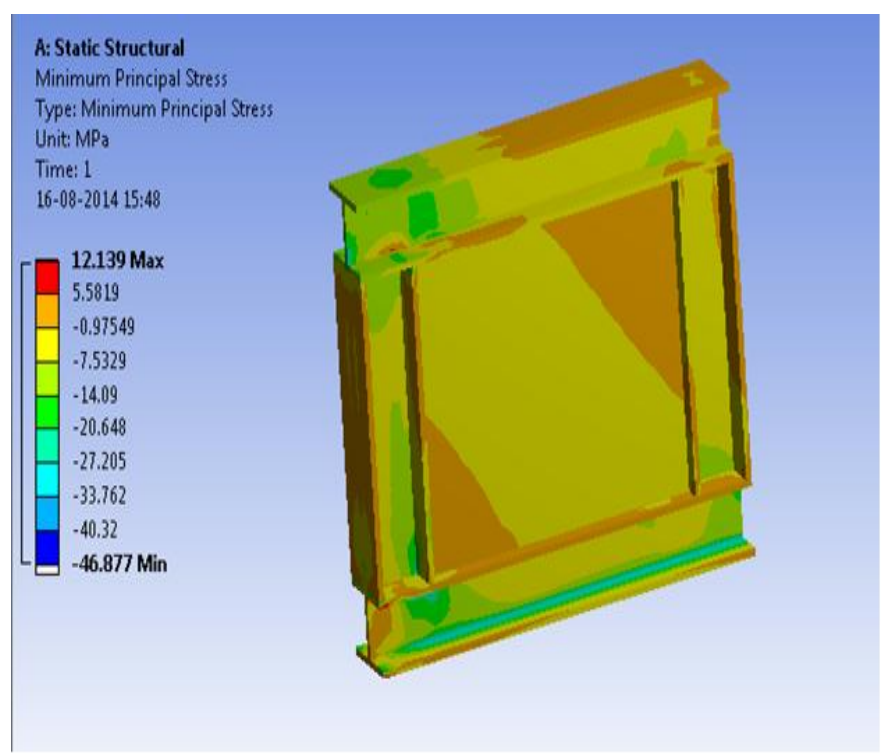

Fig.2.Riddington stiff frame: minimum principal stress $\left(\mathrm{KN} / \mathrm{m}^{2}\right)$ plot at lateral load $460 \mathrm{KN}$ by ANSYS 14.5

Table-2 Displacements for Riddington Frame \& present FE

\begin{tabular}{|l|l|l|}
\multicolumn{4}{|c}{ Analysis in ANSYS 14.5 } \\
\hline Load (KN) & $\begin{array}{l}\text { Present } \\
\text { Analysis }\end{array}$ & $\begin{array}{l}\text { Riddington } \\
\text { Frame }\end{array}$ \\
\hline 50 & 0.214646 & 0.235 \\
\hline 100 & 0.429291 & 0.4705 \\
\hline 150 & 0.643937 & 0.68 \\
\hline 200 & 0.858582 & 0.8705 \\
\hline 250 & 1.073228 & 1.129 \\
\hline
\end{tabular}

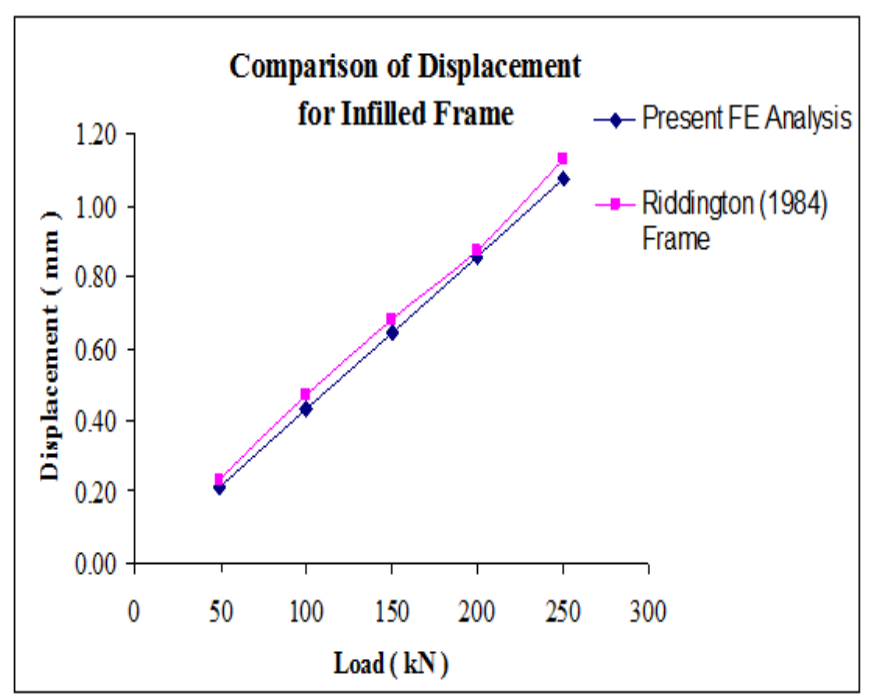

Fig 3 Graph showing Comparison of Displacement for infilled frame

\section{LINEAR ANALYSIS OF FRAME WITH SOIL.}

Three types of soil are used in the analysis namely, soft, medium stiff and hard. A validation for linear analysis of bare frame with soil and in-filled frame with soil is made and found that results are fairly comparable.

\subsection{Case 1: Linear Analysis of Bare Frame with Soil}

The model is modeled in ANSYS 14.5. Mathematical model is shown in Fig 4. Beam and columns are modeled as two dimensional frame elements having two degree of freedom per node while soil is modeled as four noded quadrilateral isoparametric elements. The lateral load is applied in $\mathrm{x}$ direction at the top of column of the structure. The Section Properties are, Size of Beam $=0.3 \mathrm{~m}$ x $0.45 \mathrm{~m} \&$ Size of Column $=0.3 \mathrm{~m} \times 0.3 \mathrm{~m}$

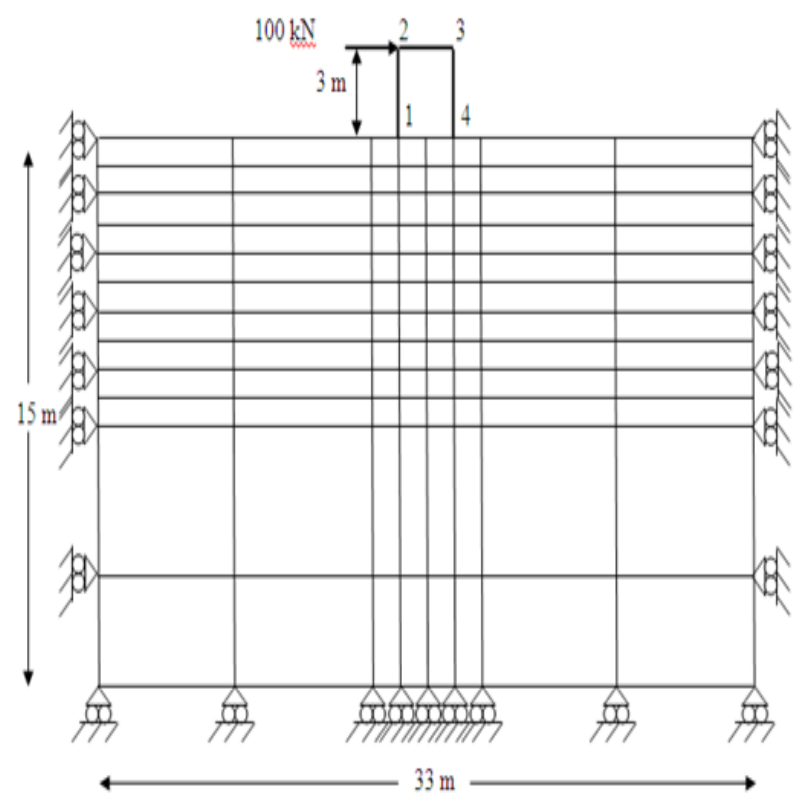

Fig 4 Finite Element Discritization of Bare Frame with soil 
Table -3 Bare frame with Soil: Maximum Displacement

\begin{tabular}{|l|l|l|l|}
\hline \multicolumn{4}{|l|}{ DISPLACEMENT } \\
\hline $\begin{array}{l}\text { Soil } \\
\text { Type }\end{array}$ & Soft Soil & Medium Stiff & Hard Soil \\
\hline Along X & $27.27 \mathrm{~mm}$ & $19.39 \mathrm{~mm}$ & $16.84 \mathrm{~mm}$ \\
\hline Along Y & $4.3 \mathrm{~mm}$ & $1.22 \mathrm{~mm}$ & $0.32 \mathrm{~mm}$ \\
\hline Rot @ Z & $\begin{array}{l}0.0035 \\
\mathrm{rad}\end{array}$ & $0.0045 \mathrm{rad}$ & $\begin{array}{l}0.0042 \\
\mathrm{rad}\end{array}$ \\
\hline
\end{tabular}

Table 4 Bare frame with soil: Maximum Bending Moments, Axial Force and Shear Force in beam and column

\begin{tabular}{|l|l|l|l|l|}
\hline \multirow{2}{*}{$\begin{array}{l}\text { Type of } \\
\text { Soil }\end{array}$} & \multicolumn{2}{|l|}{ Column } & Beam \\
\cline { 2 - 5 } & $\begin{array}{l}\text { Moment } \\
(\text { KNm) }\end{array}$ & $\begin{array}{l}\text { Force } \\
(\text { KN) }\end{array}$ & $\begin{array}{l}\text { Moment } \\
(\text { KNm })\end{array}$ & $\begin{array}{l}\text { Force } \\
(\text { KN) }\end{array}$ \\
\hline Soft & 75.3 & 49.98 & 75.05 & 49.98 \\
\hline Medium & 75.4 & 50.14 & 74.8 & 49.8 \\
\hline Hard & 75.5 & 49.72 & 74.7 & 49.72 \\
\hline
\end{tabular}

\subsection{Case 2: Linear Analysis of In-filled Frame with} Soil

The two dimensional plane frames with soil including infill is analyzed by ANSYS 14.5. The thickness of infill is taken as $0.23 \mathrm{~m}$. Rests of the structural characteristics are kept same as considered in case 1 .

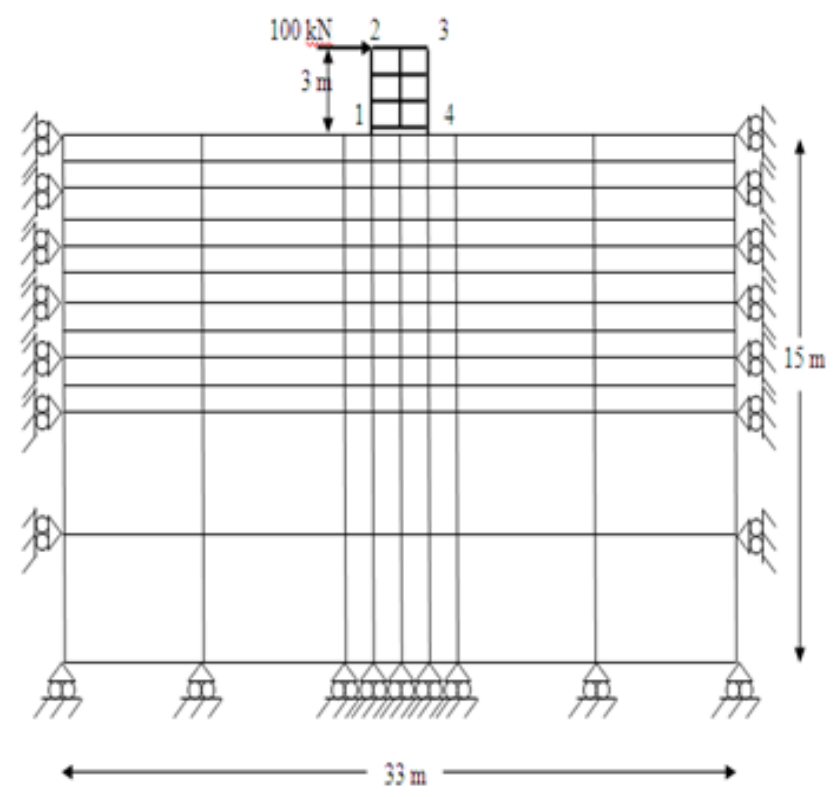

Fig 5 Finite Element Discretization of In-filled Frame With Effect of SSI

Table 5 In-filled frame with Soil: Maximum Displacement

\begin{tabular}{|l|l|l|l|}
\hline \multicolumn{2}{|l|}{ DISPLACEMENT } \\
\hline Type of Soil & Soft Soil & $\begin{array}{l}\text { Medium } \\
\text { Stiff }\end{array}$ & Hard Soil \\
\hline Along X & $14.14 \mathrm{~mm}$ & $4.37 \mathrm{~mm}$ & $2.14 \mathrm{~mm}$ \\
\hline Along Y & $5.20 \mathrm{~mm}$ & $2.1 \mathrm{~mm}$ & $0.59 \mathrm{~mm}$ \\
\hline Rot @ Z & $0.0031 \mathrm{rad}$ & $0.0010 \mathrm{rad}$ & $0.00055 \mathrm{rad}$ \\
\hline
\end{tabular}

Table 6 In-filled frame with soil: Maximum Bending Moments, Axial Force and Shear Force in beam and column

\begin{tabular}{|l|l|l|l|l|}
\hline \multirow{2}{*}{$\begin{array}{l}\text { Type of } \\
\text { Soil }\end{array}$} & \multicolumn{2}{|l}{ Column } & \multicolumn{2}{l|}{ Beam } \\
\cline { 2 - 5 } & $\begin{array}{l}\text { Moment } \\
(\text { KNm) }\end{array}$ & $\begin{array}{l}\text { Force } \\
(\text { KN) }\end{array}$ & $\begin{array}{l}\text { Moment } \\
(\text { KNm) }\end{array}$ & $\begin{array}{l}\text { Force } \\
(\text { KN) }\end{array}$ \\
\hline Soft & 2.04 & 60.4 & 2.01 & 60.4 \\
\hline Medium & 2.042 & 60.5 & 2.042 & 60.5 \\
\hline Hard & 2.04 & 60.6 & 2.04 & 60.6 \\
\hline
\end{tabular}

\section{LINEAR ANALYSIS OF BARE FRAME \& IN-}

\section{FILLED FRAME WITHOUT SOIL}

In this case linear analysis of in-filled frame $\&$ bare frame without soil is carried out and results are compared. An infilled frame is idealized using four noded isoparametric elements. The two dimensional plane frames with soil including infill is analyzed by ANSYS 14.5. The infill is modeled as four noded quadrilateral isoparametric elements. The thickness of infill is taken as $0.23 \mathrm{~m}$.

Table 7 In-filled \& Bare Frame without Soil: Maximum Displacement

\begin{tabular}{|c|c|c|}
\hline \multicolumn{3}{|l|}{ DISPLACEMENT } \\
\hline & Bare frame & In-filled Frame \\
\hline Along X direction & $0.85 \mathrm{~mm}$ & $0.428 \mathrm{~mm}$ \\
\hline Along Y direction & $0.097 \mathrm{~mm}$ & $0.068 \mathrm{~mm}$ \\
\hline Rotation@ $\mathbf{Z}$ & 0.00030 radians & 0.00021 radians \\
\hline
\end{tabular}

Table 8 Bare Frame without Soil: Maximum Bending Moment and forces in Columns and Beams

\begin{tabular}{|l|l|l|l|}
\hline \multicolumn{2}{|l|}{ Column } & Beam \\
\hline $\begin{array}{l}\text { Moment } \\
(\text { KNm) }\end{array}$ & $\begin{array}{l}\text { Axial } \\
\text { Force(KN) }\end{array}$ & $\begin{array}{l}\text { Moment } \\
(\text { KNm) }\end{array}$ & $\begin{array}{l}\text { Shear } \\
\text { Force(KN) }\end{array}$ \\
\hline 6.485 & 94.41 & 5.46 & 97.25 \\
\hline
\end{tabular}

Table 9 In-filled Frame without Soil: Maximum Bending Moment and forces in Columns and Beams

\begin{tabular}{|l|l|l|l|}
\hline Column & Beam \\
\hline $\begin{array}{l}\text { Moment } \\
\text { (KNm) }\end{array}$ & $\begin{array}{l}\text { Axial } \\
\text { Force(KN) }\end{array}$ & Moment(KNm) & $\begin{array}{l}\text { Shear } \\
\text { Force(KN) }\end{array}$ \\
\hline 4.565 & 87.41 & 4.46 & 87.25 \\
\hline
\end{tabular}

6. ANALYSIS OF FRAME WITH SOIL AS A NON-LINEAR MATERIAL.

\subsection{Analysis of Bare Frame with Soil as a Non-}

\section{Linear Material}

Analysis of bare frame with soil is done using soil as a nonlinear material. Finite elements discretization is done using Figure 4. 
Table 10 Bare frame with Soil: Maximum Displacement

\begin{tabular}{|l|l|l|l|}
\hline \multicolumn{3}{|c|}{ DISPLACEMENT } \\
\hline Soil Type & Soft Soil & Medium Stiff & Hard Soil \\
\hline Along X & $27.34 \mathrm{~mm}$ & $19.48 \mathrm{~mm}$ & $16.94 \mathrm{~mm}$ \\
\hline Along Y & $4.34 \mathrm{~mm}$ & $1.42 \mathrm{~mm}$ & $0.38 \mathrm{~mm}$ \\
\hline Rot @ Z & $0.0037 \mathrm{rad}$ & $0.0046 \mathrm{rad}$ & $0.0045 \mathrm{rad}$ \\
\hline
\end{tabular}

Table 11 Bare Frame with Soil as a Nonlinear Material:

Maximum Bending Moments, Axial Force and Shear Force in Beam and Column

\begin{tabular}{|c|c|c|c|c|}
\hline \multirow[b]{2}{*}{$\begin{array}{l}\text { Type of } \\
\text { Soil }\end{array}$} & \multicolumn{2}{|l|}{ Column } & \multicolumn{2}{|l|}{ Beam } \\
\hline & $\begin{array}{l}\text { Moment } \\
\text { (KN-m) }\end{array}$ & $\begin{array}{l}\text { Axial } \\
\text { Force } \\
(\mathrm{KN})\end{array}$ & $\begin{array}{l}\text { Moment } \\
\text { (KN-m) }\end{array}$ & $\begin{array}{l}\text { Shear } \\
\text { Force } \\
\text { (KN-m) }\end{array}$ \\
\hline \multirow{3}{*}{$\begin{array}{l}\text { Soft } \\
\text { Medium } \\
\text { Hard }\end{array}$} & 74.87 & 49.86 & 74.87 & 49.86 \\
\hline & 74.96 & 50.05 & 74.96 & 50.05 \\
\hline & 75.18 & 50.27 & 75.18 & 50.27 \\
\hline
\end{tabular}

6.2 Analysis of In-filled Frame with soil as a nonlinear material.

Analysis of in-filled frame with soil is done using soil as a nonlinear material. Finite elements discretization is done using Figure 5.

Table 12 In-filled frame with Soil: Maximum Displacement DISPLACEMENT

\begin{tabular}{|l|l|l|l|}
\hline Soil Type & Soft Soil & $\begin{array}{l}\text { Medium } \\
\text { Stiff }\end{array}$ & Hard Soil \\
\hline Along X & $14.24 \mathrm{~mm}$ & $4.47 \mathrm{~mm}$ & $2.19 \mathrm{~mm}$ \\
\hline Along Y & $5.26 \mathrm{~mm}$ & $2.18 \mathrm{~mm}$ & $0.63 \mathrm{~mm}$ \\
\hline Rot @ Z & $0.0033 \mathrm{rad}$ & $0.0011 \mathrm{rad}$ & $0.00058 \mathrm{rad}$ \\
\hline
\end{tabular}

Table 13 Infilled frame with soil: Maximum Bending Moments, Axial Force and Shear Force in beam and column

\begin{tabular}{|c|c|c|c|c|}
\hline \multirow[b]{2}{*}{ Type of Soil } & \multicolumn{2}{|l|}{ Column } & \multicolumn{2}{|l|}{ Beam } \\
\hline & $\begin{array}{l}\text { Moment } \\
\text { (KNm) }\end{array}$ & $\begin{array}{l}\text { Force } \\
(\mathbf{K N})\end{array}$ & $\begin{array}{l}\text { Moment } \\
\text { (KNm) }\end{array}$ & $\begin{array}{l}\text { Force } \\
(\mathrm{KN})\end{array}$ \\
\hline Soft & 2.09 & 60.47 & 2.081 & 60.6 \\
\hline Medium & 2.045 & 60.56 & 2.049 & 60.56 \\
\hline Hard & 2.044 & 60.63 & 2.043 & 60.74 \\
\hline
\end{tabular}

\section{CONCLUSION}

1. Analysis of bare frame with Soil Structure Interaction shows more displacement than the analysis of bare frame without Soil Structure Interaction.

2. Also analysis of bare frame with Soil Structure Interaction shows less shear force as compared with analysis of bare frame without Soil Structure Interaction.

3. Analysis of bare frame with Soil Structure Interaction shows more bending moment as compared with analysis of bare frame without Soil Structure Interaction.

4. Analysis of In-filled frame with Soil Structure Interaction shows more displacement than the analysis of In-filled frame without Soil Structure Interaction.

5. Also analysis of In-filled frame with Soil Structure Interaction shows less shear force as compared with analysis of In-filled frame without Soil Structure Interaction.

6. Analysis of In-filled frame with Soil Structure Interaction shows more bending moment as compared with analysis of In-filled frame without Soil Structure Interaction.

7. In-filled frame have higher lateral stiffness lateral load resistance than the bare frame. It was also observed that behavior of masonry in-filled RC frame was excellent in terms of strength and stiffness.

\section{REFERENCES}

[1] ACI 530.1/ASCE 6/TMS 602 Specifications for Masonry Structures.

[2] Soil Mechanics and Foundation Engineering by Dr.B.C.Punmia, Laxmi Publications.

[3] Geotechnical Engineering by Shashi K. Gulati \& Manoj Datta, Tata McGraw Hill.

[4] Finite Element Analysis by Bhavikatti S.S., New Age International Pvt Ltd Publications.

[5] Henry Burton and Gregory Deierlein Fellow (2013) "Simulation of Seismic Collapse in Non-Ductile Reinforced Concrete Frame Buildings with Masonry Infills" ASCE ,Journal of Structural Engineering, pp- 541-587.

[6] Cemalettin Dönmez1 (2013) "Seismic Performance of Wide-Beam Infill-Joist Block RC Frames in Turkey" ASCE, Journal of Performance of Constructed Facilities. pp-485-528.

[7] Cemalettin Dönmez1 (2013) "Seismic Performance of Wide-Beam Infill-Joist Block RC Frames in Turkey" ASCE, Journal of Performance of Constructed Facilities. pp-485-528.

[8] Babak Moaveni, Andreas Stavridis and P. Benson Shing, (2013) "Finite-Element Model Updating for Assessment of Progressive Damage in a 3-Story Infilled RC Frame"ASCE, Journal of Structural Engineering, pp-1665-1674.

[9] Basha\& H.B. Kaushik (2012) "Evaluation of Shear Demand on Columns of Masonry Infilled Reinforced Concrete Frames" proceeding of $15^{\text {th }}$ 
World conferance of Earthquake Engineering, pp500-510.

[10] P. G. Asteris, S. T. Antoniou, D. S. Sophianopoulos, and C. Z. Chrysostomou (2011) "Mathematical Macromodeling of Infilled Frames: State of the Art" ASCE, Journal of structural engineering, pp 15081517.

[11] Hemant B. Kaushik, Durgesh C. Rai and Sudhir K. Jain, (2009) "Effectiveness of Some Strengthening Options for Masonry-Infilled RC Frames with Open First Story" ASCE ,Journal Of Structural Engineering, pp-925-937.

[12] M. Mohammadi, V. Akrami and R. MohammadiGhazi (2011) "Methods to Improve Infilled Frame Ductility" ASCE, Journal of Structural Engineering, pp- 646-653.

[13] Asok K. Ghosh, and Amde M. Made (2002) "Finite Element Analysis of Infilled Frames" ASCE, Journal Of Structural Engineering, pp- 881-889.

[14] P. G. Asteris (2003) "Lateral Stiffness of Brick Masonry Infilled Plane Frames" ASCE, Journal Of Structural Engineering, pp-1071-1079.

[15] Behzad Fatahi And S. Hamid Reza Tabatabaiefar (2013) "Fully Nonlinear Versus Equivalent Linear Computation Method For Seismic Analysis Of MidRise Buildings On Soft Soils" ASCE, International Journal of Geomechanics ,pp- 1010-1052.

[16] Prishati Raychowdhury (2011) "Seismic response of low-rise steel moment-resisting frame (SMRF) buildings incorporating nonlinear soil-structure interaction (SSI)" Journal of Engineering Structures, pp 958-967.

[17] S. Hamid Reza Tabatabaiefar. Behzad Fatahi And Bijan Samali (2013) 'Seismic Behavior Of Building Frames Considering Dynamic Soil-Structure Interaction" ASCE,International Journal Of Geomechanics pp -409-425.

[18] Hossein Tahghighi_, Kazuo Konagai (2007) "Numerical analysis of nonlinear soil-pile group interaction under lateral loads" Soil Dynamics and Earthquake Engineering, pp- 463-474.

[19] Ali Abolmaali and Anupong Kararam (2013) "Nonlinear Finite-Element Modeling Analysis of Soil-Pipe Interaction" ASCE, International Journal Of Geomechanics , pp-197-204.

[20] Nadarajah Ravichandran, and Shada $H$. Krishnapillai, (2013) "Effect of DeformationInduced Suction in the Behavior of Unsaturated Fine-Grained Soils Using Simplified Finite-Element Model" ASCE, International Journal Of Geomechanics, pp-483-495. 